\title{
PEMERIKSAAN KADAR KALSIUM PADA MASYARAKAT DENGAN POLA MAKAN VEGETARIAN
}

\author{
Siti Nur Husnul Yusmiati' ${ }^{1)}$, Rahayu Erni Wulandari ${ }^{2)}$ \\ ${ }^{1)}$ Dosen Fakultas Ilmu Kesehatan, Universitas Maarif Hasyim Latif Sidoarjo \\ ${ }^{2)}$ Mahasiswa Program Studi D3 Teknologi Laboratorium Medik, Fakultas Ilmu Kesehatan, Universitas \\ Maarif Hasyim Latif Sidoarjo \\ Email : yusmiati1976@yahoo.co.id
}

\begin{abstract}
Vegetarians are people consuming food derived from plants or processed products, such as milk and eggs. Cereals, pulses and results nuts, tofu, tempeh and green vegetables are good source of calcium as well, but these foods contain many substances that inhibit the absorption of calcium such as fiber, phytate and oxalate, so feared vegetarians are deficient in calcium. This study is to determine the levels of calcium serum in the vegetarian by using the Colorimetric Assay. This research was conducted at the Laboratory of Clinical Chemistry Faculty of Health Sciences, Maarif Hasyim Latif University, held on March 4, 2016 until April 18, 2016. The results of a study of 25 serum samples of the vegetarian, 4 samples (16\%) showed the level of calcium in the normal range and 21 samples $(84 \%)$ below the normal value. This research it can be concluded that the majority of the vegetarian's serum calcium levels below the normal value.
\end{abstract}

Keywords: Vegetarian, Serum Calcium Levels

\section{PENDAHULUAN}

Vegetarian dikenal sebagian orang dengan pola makan yang unik karena hampir seluruh makanannya berasal dari tumbuh-tumbuhan seperti sayur, buah, padi-padian, dan kacang-kacangan. Bagi seorang vegetarian, daging dan produk alami lainnya adalah makanan yang "haram" untuk dikonsumsi (Harry, P., 2010). Alasan kaum vegetarian tidak memakan daging beragam itu. Kepercayaan agama dan alasan moral sering dijadikan dasar memilih diet ini.
Sebagian orang memang tidak menyukai daging dan sebagian lagi tidak mengkonsumsi daging karena alasan ekonomi. Daging merupakan bahan makanan yang cukup mahal.

Suatu masalah bagi penganut vegetarian adalah kekhawatiran akan defisiensi beberapa unsur penting dalam tubuh, seperti protein, kalsium, zat besi dan vitamin B12. Zat-zat gizi tersebut banyak terdapat di dalam pangan hewani, sedangkan kaum vegetarian bukanlah pemakan hewani. 
Makanan vegetarian dapat dikelompokkan menjadi beberapa jenis, diantaranya adalah makanan tradisional seperti sereal, gandum, buah-buahan, sayur - sayuran, kacang - kacangan dan sebagainya. Terdapat juga jenis produk kacang kedelai seperti tahu dan tempe yang sangat kaya akan protein (Emirfan, 2011). Selama mengonsumsi beberapa variasi makanan nabati dengan jumlah yang cukup, gaya hidup vegan merupakan pola makan gizi seimbang dan sangat menyehatkan. Bahkan, para peneliti telah membuktikan bahwa dalam banyak aspek, makanan vegan jauh lebih sehat dibandingkan dengan makanan biasa yang dikonsumsi oleh pemakan daging (Susianto, 2010).

Kalsium adalah mineral penting yang paling banyak dibutuhkan bagi tubuh manusia. Sebagai nutrisi, kalsium memegang peranan sangat penting dalam pola diet sehat dan kandungan mineral dalam tubuh. Beberapa zat dalam makanan seperti protein, asam amino, vitamin D3, dan laktat dapat meningkatkan penyerapan kalsium. Peranan kalsium dalam tubuh pada umumnya dapat dibagi menjadi dua, yaitu membantu membentuk tulang gigi dan mengatur proses biologis dalam tubuh. Keperluan kalsium terbesar pada waktu pertumbuhan, tetapi juga keperluankeperluan kalsium masih diteruskan meskipun sudah mencapai usia dewasa. Pada pembentukan tulang, bila tulang baru dibentuk maka tulang yang tua dihancurkan secara simultan (Padmasuri, 2015).

Tubuh paling siap untuk menyerap kalsium dan membangun massa tulang sebelum usia 35 tahun, namun diatas usia tersebut tetap bermanfaat untuk meningkatkan asupan kalsium. Sejumlah penelitian membuktikan bahwa pada orang di atas 65 tahun sekalipun mengonsumsi suplemen kalsium dan makanan tinggi kalsium dapat membantu menjaga kepadatan tulang dan menurunkan risiko patah tulang (Anindhita, 2011).

Hasil penelitian di Inggris terhadap vegetarian yang minum susu (lacto vegetarian) menunjukkan bahwa asupan kalsium pada lacto vegetarian lebih tinggi dari pada non vegetarian. Maksudnya, simpanan kalsium pada tulang orang vegetarian lebih tinggi daripada non vegetarian untuk kelompok umur yang sama. Hal ini dimungkinkan karena kandungan kalsium dalam daging sebenarnya tidak begitu tinggi. Pada vegetarian yang berumur mendekati 70 tahun, tidak tampak adanya penyusutan kalsium dalam tulang. Sebaliknya, bagi orang yang nonvegetarian simpanan kalsium terus menyusut untuk memenuhi kebutuhan kalsium setiap hari (Sumanto, 2009).

Berdasarkan paparan di atas, peneliti tertarik dengan penelitian tersebut dan ingin meneliti tentang kadar kalsium (Ca) serum pada penganut vegetarian dikarenakan pola makan yang dikonsumsi oleh kaum vegetarian berbeda dengan pola makan yang dikonsumsi oleh manusia pada umunya sehingga dimungkinkan akan memberikan hasil yang berbeda.

\section{METODOLOGI PENELITIAN}

\section{Waktu dan Tempat Penelitian}

Sampel dalam penelitian ini diambil secara quota sampling sebanyak 25 orang penganut vegetarian di Surabaya, yang bernama Indonesian Vegetraian Society. 
Penelitian ini dilakukan di Laboratoium Kimia Klinik Fakultas Ilmu Kesehatan Universitas Maarif Hasyim Latif Sidoarjo. Pelaksanaan penelitian dimulai 4 Maret 2016 hingga 18 April 2016.

\section{Alat dan Bahan Penelitian}

Spuit, tourniquet, tabung sentrifuge, tabung serologi, sentrifuge makro, mikro pipet, yellow tip, rak tabung, tabung centrifuge, spektrofotometer, kapas, alkohol 70\%, R1 (AMP buffer pH 10,7), R2 (o-cresolphthalein complexone, 8hydroxychinoline, hydrochloric acid, detergent), R4 (Calcium), aquabidest, serum.

\section{Prosedur}

\section{Pengolahan Sampel}

Sampel whole blood dalam tabung sentrifuge dibiarkan selama 30-45 menit pada suhu ruang, kemudian di sentrifuge selama 5 menit dengan kecepatan 2500 rpm. Serum yang terpisah dari sel-sel darah diambil menggunakan mikro pipet dan dimasukkan ke dalam tabung kosong untuk bahan pemeriksaan.

\section{Pemeriksaan Kalsium}

Disiapkan 3 tabung serologi bersih dan kering, pada masing-masing tabung diberi label balnko, standard an sampel. Pada tabung blanko diisi $400 \mu \mathrm{l}$ working reagen $(\mathrm{R} 1: \mathrm{R} 2=1$ : 1) dan $10 \mu \mathrm{l}$ aquabidest. Pada tabung standar diisi 400 $\mu \mathrm{l}$ working reagen dan $10 \mu \mathrm{l}$ R4. Pada tabung sampel diisi $400 \mu \mathrm{l}$ working reagen dan $10 \mu \mathrm{l}$ serum. Ketiga tabung tersebut dihomogenkan dan selanjutnya diinkubasi pada suhu ruang selama 5 menit. Kemudian dibaca pada alat spektrofotometer dengan $\lambda 578 \mathrm{~nm}$.

\section{Pasca Analisa}

Hasil pemeriksaan yang didapat dicatat dalam buku pasien dan dikumpulkan sebagai data. Nilai kalsium dalam serum yang dianjurkan adalah 8,60 $-10,2 \mathrm{mg} / \mathrm{dl}$.

\section{Analisis Data}

Penelitian ini merupakan penelitian observasional. Data yang diperoleh disajikan dalam bentuk tabel dan diagram untuk mengetahui gambaran tentang pemeriksaan kadar kalsium pada penganut vegetarian yang bernama Indonesian Vegetraian Society di Surabaya.

\section{HASIL DAN PEMBAHASAN}

\section{Hasil}

Hasil penelitian pada 25 sampel pada kaum vegetarian yang bernama Indonesian Vegetraian Society di Surabaya disajikan pada Tabel 1. 
Tabel 1. Data Hasil Pemeriksaan Kadar Kalsium Serum pada Kaum Vegetarian

\begin{tabular}{lccccl}
\hline No & $\begin{array}{c}\text { Kode } \\
\text { Sampel }\end{array}$ & Umur & $\begin{array}{c}\text { Jenis } \\
\text { Kelamin }\end{array}$ & Hasil & Keterangan \\
\hline 1 & MW & 27 & P & $7,280 \mathrm{mg} / \mathrm{dl}$ & Dibawah nilai normal \\
\hline 2 & GY & 28 & L & $6,155 \mathrm{mg} / \mathrm{dl}$ & Dibawah nilai normal \\
\hline 3 & HK & 20 & L & $5,081 \mathrm{mg} / \mathrm{dl}$ & Dibawah nilai normal \\
\hline 4 & RI & 39 & P & $7,178 \mathrm{mg} / \mathrm{dl}$ & Dibawah nilai normal \\
\hline 5 & YA & 23 & P & $4,450 \mathrm{mg} / \mathrm{dl}$ & Dibawah nilai normal \\
\hline 6 & MS & 25 & P & $8,721 \mathrm{mg} / \mathrm{dl}$ & Normal \\
\hline 7 & LH & 23 & P & $4,083 \mathrm{mg} / \mathrm{dl}$ & Dibawah nilai normal \\
\hline 8 & AA & 31 & P & $2,613 \mathrm{mg} / \mathrm{dl}$ & Dibawah nilai normal \\
\hline 9 & SI & 40 & P & $7,153 \mathrm{mg} / \mathrm{dl}$ & Dibawah nilai normal \\
\hline 10 & TO & 23 & L & $4,450 \mathrm{mg} / \mathrm{dl}$ & Dibawah nilai normal \\
\hline 11 & VY & 38 & P & $4,054 \mathrm{mg} / \mathrm{dl}$ & Dibawah nilai normal \\
\hline 12 & GN & 18 & P & $3,829 \mathrm{mg} / \mathrm{dl}$ & Dibawah nilai normal \\
\hline 13 & LW & 25 & $\mathrm{~L}$ & $8,673 \mathrm{mg} / \mathrm{dl}$ & Normal \\
\hline 14 & WJ & 30 & L & $3,766 \mathrm{mg} / \mathrm{dl}$ & Dibawah nilai normal \\
\hline 15 & GI & 29 & P & $5,405 \mathrm{mg} / \mathrm{dl}$ & Dibawah nilai normal \\
\hline 16 & IJ & 25 & L & $3,838 \mathrm{mg} / \mathrm{dl}$ & Dibawah nilai normal \\
\hline 17 & HT & 40 & $\mathrm{~L}$ & $5,636 \mathrm{mg} / \mathrm{dl}$ & Dibawah nilai normal \\
\hline 18 & SW & 36 & L & $5,027 \mathrm{mg} / \mathrm{dl}$ & Dibawah nilai normal \\
\hline 19 & NA & 26 & P & $5,333 \mathrm{mg} / \mathrm{dl}$ & Dibawah nilai normal \\
\hline 20 & XX & 19 & P & $4,883 \mathrm{mg} / \mathrm{dl}$ & Dibawah nilai normal \\
\hline 21 & AR & 34 & L & $6,142 \mathrm{mg} / \mathrm{dl}$ & Dibawah nilai normal \\
\hline 22 & DI & 28 & P & $4,440 \mathrm{mg} / \mathrm{dl}$ & Dibawah nilai normal \\
\hline 23 & IN & 28 & $\mathrm{~L}$ & $8,658 \mathrm{mg} / \mathrm{dl}$ & Normal \\
\hline 24 & IS & 34 & P & $5,191 \mathrm{mg} / \mathrm{dl}$ & Dibawah nilai normal \\
\hline 25 & AR & 35 & P & $9,405 \mathrm{mg} / \mathrm{dl}$ & Normal \\
\hline K & N & & & \\
\hline
\end{tabular}

Keterangan : Nilai normal kadar kalsium : 8,60 - 10,2 mg/dl

Untuk mengetahui prosentase kadar kalsium pada penganut vegetarian di surabaya menggunakan rumus : $\frac{X}{N} \times 100 \%$, dimana $\mathrm{X}$ adalah hasil pemeriksaan dan $\mathrm{N}$ adalah jumlah sampel yang diperiksa.

1. Prosentase kadar kalsium pada penganut vegetarian dalam batas normal ada 4 orang dari 25 sampel yaitu : $\frac{4}{25} \times 100 \%=16 \%$
2. Prosentase kadar kalsium pada penganut vegetarian dalam batas di bawah nilai normal ada 21 orang dari 25 sampel yaitu : $\frac{21}{25} \times 100 \%=84 \%$ Prosentase kadar kolesterol dalam batas normal sebesar $16 \%$ (4 orang) dan $84 \%$ (21 orang) di bawah nilai normal. 


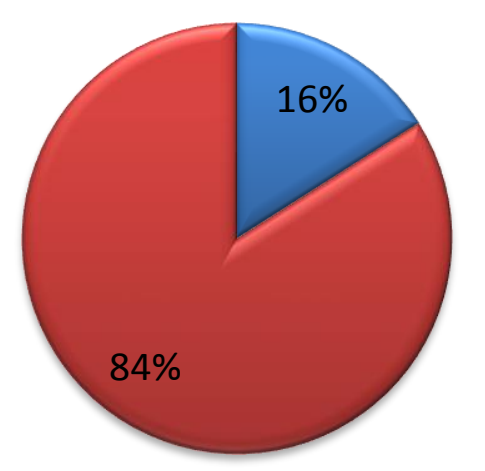

Normal

Dibawah Normal

Gambar 1. Diagram Pie prosentase kadar kalsium (Ca) serum pada kaum vegetarian yang normal dan di bawah nilai normal

\section{Pembahasan}

Dari hasil pemeriksaan yang tercantum dalam diagram di atas diketahui bahwa sebagian besar kadar kalsium pada penganut vegetarian yakni dibawah nilai normal. Hal ini, dimungkinkan pola makan yang dianut oleh vegetarian sebagian besar merupakan bahan makan rendah kalsium.

Sumber kalsium terbagi dua, yaitu hewani dan nabati. Bahan makanan hewani yang mengandung kalsium antara lain adalah Ikan, Udang, susu, kuning telur, dan daging sapi. Bahan makanan yang mengandung kalsium nabati bisa diperoleh dari sayuran daun hijau seperti sawi, bayam, brokoli,daun pepaya,daun singkong, daun labu. Selain itu biji-bijian (kenari, wijen, almond) dan kacangkacangan serta hasil olahannya (kedelai, kacang merah, kacang polo, tempe, tahu) (Sativani, 2011).

Kalsium tidak hanya komponen utama dari tulang, tetapi juga sangat diperlukan untuk pembekuan darah dan untuk kontraksi setiap otot dalam tubuh, termasuk jantung. Ini juga merupakan mineral penting untuk berfungsinya sel-sel otak. Kalsium disimpan dalam tulang. Kalsium dikeluarkan dari tulang ke dalam darah, serta penyerapan pada ginjal atau usus, diatur oleh hormon paratiroid bersama dengan vitamin $D$. Dengan demikian, hormon paratiroid dan vitamin D memiliki fungsi meningkatkan kadar kalsium dalam darah. Sehingga kadar kalsium, dapat mempengaruhi sekresi hormon paratiroid. Rendahnya tingkat kalsium dalam darah menginduksi sekresi hormon paratiroid, sehingga terjadi peningkatan kadar kalsium. Di sisi lain, tingkat tinggi kalsium dalam darah menghambat sekresi hormon paratiroid, yang menyebabkan penurunan kadar kalsium. Dengan cara ini, kadar kalsium dalam darah tetap dalam tingkat normal (Budisma,2015).

Dalam keadaan normal sebanyak 30$50 \%$ kalsium yang dikonsumsi diabsorpsi di tubuh. Kemampuan absorpsi lebih tinggi pada masa pertumbuhan, dan menurun pada proses menua. Kemampuan absorpsi pada laki - laki lebih tinggi daripada perempuan pada semua golongan usia (Almatsier, 2004). Absorpsi kalsium 
terutama terjadi dibagian atas usus halus, yaitu duodenum. Dalam keadaan normal, dari sekitar $1000 \mathrm{mg} \mathrm{Ca++} \mathrm{yang} \mathrm{rata-rata}$ dikonsumsi per hari, hanya sekitar dua pertiga yang diserap di usus halus dan sisanya keluar melalui feses (Sherwood, 2001 dalam Gaahyatri, 2015). Kalsium membutuhkan pH 6 agar dapat berada dalam keadaan terlarut. Absorpsi kalsium terutama dilakukan secara aktif dengan menggunakan alat ukur protein-pengikat kalsium. Absorpsi pasif terjadi pada permukaan saluran cerna. Banyak faktor mempengaruhi absorpsi kalsium. Kalsium hanya bisa diabsorpsi bila terdapat dalam bentuk larut-air dan tidak mengendap karena unsur makanan lain, seperti oksalat.

Faktor yang meningkatkan penyerapan kalsium adalah Semakin tinggi kebutuhan dan semakin rendah persediaan kalsium dalam tubuh semakin efesien absorpsi kalsium. Peningkatan kebutuhan terjadi pada pertumbuhan, kehamilan, menyusui, defesiensi kalsium dan tingkat aktivitas fisik yang meningkatkan densitas tulang. Jumlah kalsium yang dikonsumsi mempengaruhi absorpsi kalsium (Almatsier, 2004). Status kalsium ditentukan oleh kombinasi faktor nutrisi dan hormonal yang dengan interaksi kompleks menentukan jumlah kalsium tersedia yang dapat diserap. Vitamin D meningkatkan absorpsi pada mukosa usus dengan cara merangsang produksi-protein pengikat kalsium. Absorpsi kalsium paling baik terjadi dalam keadaan asam. Asam klorida yang dikeluarkan lambung membantu absorpsi kalsium dengan cara menurunkn $\mathrm{pH}$ di bagian atas duodenum. Asam amino tertentu meningkatkan $\mathrm{pH}$ salura cerna, dengan demikian membantu absorpsi. Aktivitas fisik berpengaruh baik terhadap absorpsi kalsium. Laktosa meningkatkan absorpsi bila tersedia cukup enzim laktase. Sebaliknya, bila terdapat defesiensi laktase, laktosa mencegah absorpsi kalsium. Lemak meningkatkan waktu transit makanan melalui saluran cerna, dengan demikian memberi waktu lebih banyak untuk absorpsi kalsium (Almatsier, 2004).

Sedangkan faktor yang menghambat penyerapan kalsium adalah kekurangan vitamin D dalam bentuk aktif. Asam oksalat yang terdapat dalam bayam, sayuran lain dan kakao membentuk garam kalsium oksalat yang tidak larut, sehingga menghambat absorpsi kalsium (Almatsier, 2004). Selain itu, kosumsi tinggi serat dapat menurunkan absorpsi kalsium, diduga karena serat menurunkan waktu transit makanan dalam saluran cerna sehingga mengurangi kesempatan untuk absorpsi (Guthrie dan Picciano, 1995; Krummel, 1996; Gaahyatri, 2015). Rasio konsumsi kalsium fosfor agar dapat dimanfatkan secara optimal dianjurkan adalah 1:1 dalam makanan, konsumsi fosfor yang lebih tinggi dapat mengahambat absorpsi kalsium karena fosfor dalam suasana basa membentuk kalsium fosfat yang tidak larut air (Khomsan, 1996; Gaahyatri, 2015).

Konsumsi kalsium hendaknya tidak melebihi 2500 mg sehari. Kelebihan kalsium dapat menimbulkan batu ginjal atau gangguan ginjal. Disamping itu, dapat menyebabkan konstipasi (susah buang air besar). Kelebihan kalsium bisa terjadi bila menggunakan suplemen kalsium berupa tablet atau bentuk lain (Almatsier, 2004). 


\section{KESIMPULAN}

Dari hasil penelitian yang dilakukan di Laboratorium Kimia Klinik Fakultas Ilmu Kesehatan Universitas Maarif Hasyim Latif Sidoarjo, didapatkan hasil sebanyak $84 \%$ pada penganut vegetarian mempunyai kadar kalsium serum di bawah nilai normal, yaitu kurang dari $8,6 \mathrm{mg} / \mathrm{dl}$. Sedangkan hanya $16 \%$ penganut vegetarian yang memiliki kadar kalsium serum dalam batas normal, yaitu 8,6 - 10,2 $\mathrm{mg} / \mathrm{dl}$.

\section{UCAPAN TERIMAKASIH}

Penulis mengucapkan terimakasih kepada semua pihak yang telah banyak membantu selama peelitian ini berlangsung. Terimakasih kepada staf Laboratorium Kimia Klinik yang juga sangat membantu selama proses analitik berlangsung.

\section{DAFTAR PUSTAKA}

Almatsier Sunita. 2004. Prinsip Dasar Ilmu Gizi. Gramedia Pustaka Utama. Jakarta.

Anindhita Syahbi. 2011. Kepadatan Tulang pada Vegetarian Vegan dan No Vegan. Skripsi Universitas Diponegoro. Semarang. Ilmu Gizi : 7-8.

Budisma. 2015. Fungsi Kelenjar Paratiroid. http://www.kalsium.com/Fungsi.Kele njar.ParatiroidBudisma.htm. Diakses Juni 2016.

Emirfan, T.M. 2011. Healthy Habits You Must Know. Javalitera. Yogyakarta.

Gaahyatri. 2015. Pola Asupan Kalsium Pada Mahasiswa Fakultas Kedokteran Universitas Sumatera
Utara. Karya Tulis Ilmiah. Universitas Sumatera Utara. Medan. Guthrie A. Helen and Picciano F.M. 1995. Human Nutrition. Mosby-Year Book Inc. USA.

Harry, P. 2010. Bebas Kanker Tanpa Daging. Jogja Great Publisher. Yogyakarta.

Khomsan, Ali. 2000. Teknik Pengukuran Pengetahuan Gizi. Jurusan Gizi Masyarakat dan Sumber Daya Keluarga. IPB. Bogor.

Krummel, D.A. and Etherton, K. 1996. Nutrition In Women's Health. Aspen Publisher. USA.

Padmasuri Karina. 2015. I'm A Happy Vegetarian. CV. Solusi Distribusi. Yogyakarta.

Sativani Riza. 2011. Mekanisme Absorbsi Kalsium.

http://oryzasativa135rsh.blogspot.co.i d/2011/06/mekanisme-absorbsicalsium.html. Diakses Juli 2016.

Sherwood, L. 2001. Fisiologi Manusia dari Sel ke Sistem. Edisi 2. EGC. Jakarta. Sumanto Agus. 2009. Tetap Langsing dan Sehat dengan Terapi Diet. Agro Media Pustaka. Jakarta.

Susianto. 2010. The Miracle of Vegan. Qanita. Jakarta Selatan. 